\title{
PANGGILAN DAN PERUTUSAN AWAM KATOLIK DI TENGAH MASYARAKAT
}

\author{
Oleh: \\ Ola Rongan Wilhelmus \\ STKIP Widya Yuwana
}

\begin{abstract}
The call and mission of Catholic laymen in the Church and in the midst of society is often associated with the parable of the hired people in the Lord's vineyard (Mt 20: 1-16). Changes and various problems which have been occurring in the Church and in the community at all times urge the Catholic community to respond immediately. Catholic laypeople are prohibited from becoming spectators when facing various problems and changes being occurred. The question is how and to what extent has the layman tried to live a family life and organize economic, political, legal, social, cultural activities, etc. according to God's plan and will?Answering the question, this paper intends to describe a number of main things, namely: first, lay call and mission in the community, second, Spontaneously answer of lay man to the call and mission of God; third, the perfection and novelty of life; and fourth, the call for holiness of life. This writing is inspired by the parable of the hired men in the vineyard (Mt 20: 1-8).
\end{abstract}

Keywords: call, mission, lay, society

\section{PENDAHULUAN}

Dunia yang ditandai dengan berbagai kegiatan ekonomi, politik, pendidikan, hukum, budaya, pemerintahan, serta kemajuan komunikasi dan teknologi digital saat ini tidak jarang membawa kegembiraan, harapan, kemenangan, kecemasan, ketakutan, kekalahan dan kegagalan hidup. Dunia dengan warna-warni hidup seperti ini merupakan kebun anggur Allah. Dalam dunia seperti ini setiap awam terpanggil untuk mewujudkan tugas perutusan Ilahi yaitu menjadi garam dan cahaya dunia.Pengalaman akan warna warni hidup yang datang silih berganti dan bahkan bersamaan itu diungkapkan Allah sendiri melalui perumpamaan tentang lalang di antara gandum (Mat 13: 24-30).

Tulisan ini bermaksud memberikan suatu uraian tentang panggilan dan perutusan umat beriman di dalam Gereja dan di tengah masyarakat. melalui berbagai upaya di dalam kehidupan keluarga, dunia pendidikan, ekonomi, politik, hukum, sosial dan budaya sesuai kehendak dan rencana Allah. Pertanyaannya ialah bagaimana dan sejauh mana awam telah berupaya menjalani kehidupan keluarga serta menata kegiatan ekonomi, politik, hukum, sosial, budaya, dll sesuai rencana dan kehendak Allah? Tulisan ini bermaksud menguraikan beberapa hal 
pokok yaitu: pertama, panggilan dan perutusan awam di tengah masyarakat; kedua, Allah menghendaki jawaban spontan; ketiga, kesempurnaan dan kebaruan hidup; dan keempat, tuntuan akan kekudusan hidup. Tulisan ini dijiwai oleh “Perumpamaan tentang orang-orang upahan di kebun anggur (Mat 20: 1-8).

\section{PANGGILAN DAN PERUTUSAN DI TENGAH MASYARAKAT}

Panggilan dan perutusan awam Katolik di dalam Gereja dan di tengah masyarakat sering dikaitkan dengan perumpamaan tentang: orang-orang upahan di kebun anggur Tuhan (Mt 20: 1-16). Tentang hal ini Injil Matius mengatakan:

"Adapun hal kerajaan Allah itu sama seperti seorang tuan rumah yang pagi-pagi benar keluar mencari para pekerja untuk bekerja di kebun anggurnya.Setelah ia sepakat dengan para pekerja itu mengenai upah sehari sedinar maka ia menyuruh mereka pergi ke kebun anggurnya” (Mt 20:1-2).

Kisah Injil ini hendak mengatakan bahwa Allah memiliki kebun anggur yang sangat luas. Karena itu Allah sendiri membutuhkan banyak pekerja laki-laki dan perempuan untuk bekerja di kebun anggur ini. Para pekerja itu dicari, dipanggil serta diutus langsung oleh Allah sendiri untuk bekerja di kebun anggur (John Paul II. 1987). Kebun anggur Allah itu adalah "seluruh dunia dan segenap alam raya ini”. Injil Mat 13:38 mengatakan bahwa ladang Tuhan adalah seluruh dunia. Kebun anggur ini perlu digarap dan dikelola para pekerja seturut kehendak Allah dan bukannya seturut kehendak pekerja. Para pekerja kebun anggur ini tidak hanya terbatas pada para gembala umat (diakon, imam dan uskup), serta biarawan/biarawati, rohaniwan/rohaniwati, tetapi juga para awam Katolik.

Allah memanggil dan mengutus para pekerja, terutama kaum awam untuk menata dunia atau kebun anggur melalui berbagai usaha menata mengatur kehidupan keluarga, dunia pendidikan, ekonomi, politik, hukum, sosial, budaya dan lain-lainnya seturut kehendak dan rencanaNya. Alasan menata kehidupan dunia sehari-hari sesuai kehendak Allah, yaitu supaya setiap kegiatan yang dilakukan dapat menjadi tanda kasih, berkat dan kebaikan Allah untuk banyak orang. Allah menghendaki agar setiap awam yang terlibat dalam kegiatan dan pelayanan di lingkungan sekolah, kantor, organisasi, perkumpulan baik swasta maupun pemerintah dapat menjadi tanda kasih, kebaikan atau berkat Allah untuk banyak orang. Karena itu, setiap umat beriman, terutama kaum awam selalu perlu bertanya kepada diri sendiri tentang sudah sejauh mana pekerjaan dan pelayanan yang dikerjakan sehari-hari sudah menjadi tanda berkat dan kebaikan Allah bagi banyak orang? (John Paul II. 1987). Allah terus mencari dan mengundangpara pekerja untuk bekerja di kebun anggur:

"Dan kira-kira pukul Sembilan pagi, Ia keluar pula dan dilihatnya ada pula orang-orang lain yang menganggur di pasar, katanya 
kepada mereka: pergi jugalah kamu ke kebun anggurku, dan apa yang pantas akan kuberikan kepadamu. Dan merekapun pergi” (Mat 20:3-4).

Sejak 2000-an tahun lalu, Allah terus memanggil para pekerja melalui Yesus Kristus untuk bekerja di kebun anggur: "pergilah juga kamu ke kebun anggurku". Panggilan ini terus bergema sepanjang sejarah. Yesus tetap menyeruhkan panggilan ini kepada setiap pengikut-Nya yang hidup dan berkarya di tengah dunia dalam setiap zaman. Demikian pula Gereja Katolik sebagai mempelai Kristus tidak pernah berhenti mendesak para pengikut-Nya terutama kaum awam supaya terus membuka hati dan telinga terhadap suara Tuhan yang memanggil dan mengutusnya ke tengah dunia ini untuk menjadi tanda berkat, kasih dan kebaikan Tuhan bagi setiap orang di dunia ini tanpa memandang sekat atau perbedaan agama, etnik, budaya, kelas sosial dan ekonomi, afiliasi politik, gender dan lain-lain. Allah mengutus para awam ke tengah dunia untuk menjadi “Sakramen Keselamatan Universal” (John Paul II. 1987).

Firman Tuhan: "Pergi jugalah kamu ke kebun anggurku” (Mat 20:7). Panggilan Tuhan ini tidak hanya dialamatkan kepada para pelayan dan gembala umat (diakon, imam dan uskup), biarawan/ biarawati, serta rohaniwan/rohaniwati, sebaliknya, dialamatkan secara khusus kepada awam yang telah menerima tugas perutusan Gereja melalui sakramen pembaptisan untuk meragakan rahmat, kasih dan kebaikan Allah di tengah dunia dan masyarakat. Dalam mewartakan kasih dan kebaikan Tuhan ini, St. Gregorius Agung (1155) menasehati umat beriman: "Rawatilah selalu prilaku hidupmu, cintailah semua orang dan pastikan bahwa dirimu sendiri merupakan seorang pekerja di landang Tuhan”. Nasehat St. Gregorius Agung ini mengandung arti bahwa untuk menjadi pewarta yang efektif tentang kasih dan kebaikan Tuhan seseorang harus selalu merawat dan memelihara dirinya sendiri dengan terus melakukan perbuatan kasih dan kebaikan. Ia sendiri perlu memiliki hubungan yang intim dengan Tuhan serta mengalami dan merasahkan pengalaman akan kasih dan kebaikan itu.

Konsili Vatikan II telah mengingatkan setiap umat beriman tentang panggilan untuk bekerja di ladang Tuhan. Panggilan ini hendaknya dijawab dengan cepat, spontan dan penuh suka cita. Injil Matius 20:4 mengatakan bahwa setelah para pekerja itu mendengarkan panggilan Tuhan itu maka merekapun segera pergi ke kebun anggur. Hal ini menunjukkan bahwa mereka memiliki kepekaan dan ketaatan luar biasa terhadap suara Tuhan.Mereka segera bergegas pergi bekerja di kebun anggur Tuhan. Umat beriman, terutama para awam hendaknya memiliki kepekaan yang sama terhadap suara panggilan Tuhan dan segera memberikan jawaban positif terhadap panggilan Tuhan ini (LG. Art. 48)

Gereja melalui sinode para uskup di Roma pada tahun 1987 menyuarakan lagi panggilan Tuhan untuk bekerja di kebun anggur: "Kamu pergilah juga ke 
kebun anggurku”. Panggilan ini dikumandangkan lagi ketika itu dengan tujuan memberi inspirasi dan dorongan bagi kaum awam supaya lebih berperan aktif menjalankan tugas panggilan dan perutusan di tengah kehidupan keluarga, bangsa, negara dan masyarakat. Panggilan ini terus dikumandangkan Gereja dengan maksud mendorong kerjasama antara para awam dengan imam, biarawan/biarawati, rohaniwan/rohaniwatimembangun Gereja sebagai tanda keselamatan universal di tengah dunia melalui bidang pelayanan liturgi, pewartaan Sabda Allah, pendidikan iman, dan berbagai bentuk kegiatan kerasulan lainnya (AA. Art. 33).

Di tengah keterlibatan umat beriman, terutama kaum awam dalam menjalankan tugas perutusan Gereja, Konsili Vatikan II mengingatkan segenap awam untuk menghindari dua jenis godaan. Godaan pertama yang harus dihindari ialah semangat keterlibatan kaum awam dalam berbagai kegiatan Gereja tidak boleh membuat awam mengabaikan dan gagal menjalankan tugas dan tanggungjawabnya dalam membangun, mengembangkan dan menata dunia profesional, sosial, ekonomi, politik, hukum, budaya dan lain-lain yang harus digeluti awam. Godaan kedua ialah godaan untuk memisahkan iman dari praktek atau prilaku hidupaktual sehari-hari di tengah keluarga dan masyarakat terutama ketika menjalankan kegiatan profesional dalam bidang kehidupan sosial, ekonomi, politik, hukum, budaya dan sebagainya (GS. Art. 7; AA. Art.33).

\section{PANGGILAN ALLAH MEMBUTUHKAN TANGGAPAN SPONTAN}

Tuhan bersabda: “Mengapa kamu tetap berdiri disini sepanjang hari”? (Mat 20:6). Kata-kata Yesus ini mengandung teguran bahwa umat beriman, khususnya kaum awam tidak boleh bersikap pasif dan masa bodoh terhadap panggilan Tuhan untuk bekerja di kebun anggur. Tuhan menghendaki setiap umat beriman memiliki kepekaan tinggi terhadap panggilan ini dan segera bergegas pergi bekerja di ladang Tuhan. Mulailah sekarang ini juga menata kebun anggur Tuhan dengan cara menata kehidupan keluarga, pendidikan, ekonomi, politik, sosial dan budaya seturut rencana dan kehendak Allah. Umat beriman dilarang bersikap apatis, masa bodoh dan malas terhadap undangan Allah untuk bekerja di kebun anggur, sebaliknya, umat Allah hendaknya berinisiatif menata kebun anggur Tuhan yaitu dunia kerja dan hidup konkrit sehari-hari seturut kehendak Allah. Hal ini perlu dilakukan agar kasih dan kebaikan Allah dapat tersalur dan dirasakan banyak orang melalui perbuatan-perbuatan baik yang dikerjakan (GS. Art.7).

Perubahan serta berbagai persoalan yang terjadi di dalam Gereja dan di tengah masyarakat setiap saat mendesak awam Katolik untuksegera memberi respon. Awam Katolik dilarang menjadi penonton saat menghadapi berbagai 
macam persoalan yang muncul dan perubahan yang terjadi. Karena itu Allah mengulagi lagi undangannya untuk bekerja di kebun anggur. Sabda Tuhan: "kirakira pukul 5 petang ia keluar lagi dan mendapatkan orang-orang lain pula, lalu katanya kepada mereka, mengapa kamu menganggur disini sepanjang hari? Lalu kata mereka kepadaNya: karena tidak ada orang yang mengupah kami. Lalu katanya kepada mereka: pergilah juga kamu ke kebun anggurku” (Mat 20:6-7).

Pekerjaan di kebun anggur Tuhan membutuhkan banyak pekerja. Karena itu pengangguran sesungguhnya tidak boleh terjadi. Undangan bagi awam untuk bekerja di kebun Anggur terus datang dan bergemah. Undangan ini menuntut respon positif yang diungkapkan antara lain melalui keterbukaan para awam terhadap bimbingan Roh Kudus untuk memahami dan segera menyikapi tandatanda zaman, peristiwa-peristiwa hidup, harapan, kecemasan dan kerinduan manusia sesuai kehendak Tuhan. Iman kepada Allah menuntut awam untuk membaca serta mewujudkan rencana dan kehendak Allahdalam setiap peristiwa konkrit, tanda-tanda zaman, harapan dan kecemasan hidup manusia (Bdk. GS. Art. 7).

Tidak dapat disangkal bahwa masyarakat dan dunia saat ini terus mengalami dan menyaksikan berbagai bentuk kegelisahaan, kecemasan, harapan, serta pengalaman akan kekalahan dan kemenangan. Dunia yang terus diisi dengan berbagai kegiatan ekonomi, politik, pendidikan, hukum, budaya ini tidak jarang mendatangkan berbagai pengalaman akan kegembiraan, harapan, kemenangan, kegagalan dan kecemasan hidup ini (LG Art. 3). Dunia dengan warna-warni kehidupan seperti ini merupakan kebun anggur Allah. Dalam dunia seperti ini setiap pengikut Kristus terpanggil untuk mewujudkan tugas perutusan Ilahi yaitu menjadi garam dan terang dunia (Bdk Mat 5: 13-14).

Awam diutus menjadi terang dan garam dunia karena dunia yang penuh dengan berbagai kesibukan hidup dan terus mengalami perubahan ini selalu membawa berbagai pengalaman hidup susah dan senang, menang dan kalah, gelap dan terang yang datang secara silih berganti dan bahkan bersamaan. Kitab Suci mengatakan bahwa gandum dan tanaman liar sering tumbuh bersama-sama di ladang (Mat 13:26). Artinya pengalaman hidup susah dan senang, menang dan kalah, terang dan gelap sering datang silih berganti dan bahkan bersamaan.

Dunia membutuhkan terang atau cahaya Ilahi untuk membedakan kebaikan dan kejahatan, kekalahan dan kemenangan, terang dan gelap atau gandum dan tanaman liar. Cahaya ini nampak dalam sikap dan perilaku hidup yang baik, benar, adil, damai, penuh perhatian dan kasih sayang sebagaimana diajarkan Yesus sendiri. Sikap dan prilaku hidup konkrit ini hendaknya diragakan secara konkret oleh setiap awam sebagai pengikut Kristus. Sikap dan perilaku ini merupakan tanda kekudusan, kesempurnaan dan kebaruan hidup awam di tengah dunia dan masyarakat (Gs. Art. 7; AA. 33). 


\section{KESEMPURNAAN DAN KEBARUAN HIDUP}

Kesempurnaan dan kebaruan hidup awam sebagai umat beriman Kristiani merupakan status dan gelar hidup baru yang diperoleh awam karena pembabtisan dalam nama Yesus Kristus. Melalui pembabtisan ini awam Katolik memperoleh rahmat dan panggilan akan kebaruan dan kesempurnaan hidup. Meskipun demikian, panggilan kepada kebaruan dan kesempurnaan hidup ini tidak menghilangkan karakter sekularistik dalam diri setiap umat beriman, terutama kaum awam. Paus Yohanes Paulus ke IV mengatakan bahwa Gereja tetap memiliki dimensi sekularistikyang otentik. Dimensi ini merupakan kodrat dan tugas perutusan Gereja. Kodrat sekularistik ini berakar dalam misteri inkarnasi Allah menjadi manusia (GS Art.7).

Di tengah dunia yang sekularistik ini, awam sebagai Gereja Umat Allah dipanggil untuk terlibat aktif dalam tata kelola dan pembaharuan dunia ini. Karena itu setiap awam sebagai anggota Gereja patut mengambil bagian dalam tata kelola dunia yang berdimensi sekularistik walaupun dengan cara berbeda. Konsili Vatikan II menegaskan bahwa upaya mewujudkan fungsi awam dalam tata kelola dunia yang sekularistik ini merupakan tanggung jawab utama para awam. Perwujudan fungsi awam dalam tata kelola dunia ini diungkapkan secara konkrit melalui berbagai perkerjaan dan profesi atau melalui berbagai kegiatan awam sehari-hari dalam bidang sosial, budaya, pendidikan, politik, ekonomi, hukum, pemerintahan dll. Pekerjaan dan profesi ini perlu dilakukan selaras dengan rencana dan kehendak Allah yaitu demi kemuliaan Allah serta kebaikan dan keselamatan universal (LG Art. 48).

Dengan menjalakan tugas dan pekerjaan selaras dengan kehendak Allah ini awam dapat menemukan arti dan makna hidup yang sesungguhnya sebagai umat beriman. Sabda Allah itu menjadikan semua orang yang percaya kepadaNya sebagai anak-anak Allah. Sabda itu menguduskan dan membeharui hubungan manusisawi dan semua ikatan sosial manusia. Sabda Allah itu ialah Yesus putra Allah itu sendiri (Bdk. Yoh 1:1-18). Dunia ini merupakan tempat dan sarana bagi kaum awam untuk menjalani panggilan hidup Kristiani. Di tengah dunia yang sekularistik ini, awam beriman tidak dipanggil untuk meninggalkan hidup dan aktivitas yang bersifat sekularistik sebab rahmat pembabtisan yang diterima itu tidak memisahkan manusia dari situasi kehidupan dunia yang sekular ini. Rasul Santu Paulus mengatakan: "Hendaklah setiap orang hidup dalam keadaan sebagaimana waktu ia dipanggil Allah” (1 Kor 7:24).

Awam dipanggil, diutus dan dibimbing Allah sendiri melalui Sabda-Nya untuk kesempurnaan dan kebaruan hidup melalui cara hidup dan perbuatan yang dijiwai oleh iman dan kasih yang diajarkan Yesus sendiri. Dengan demikian kehadiran dan kegiatan awam di dunia ini bukan hanya merupakan suatu realitas sosial dan manusiawi malainkan realitas pengudusan Ilahi. Kehadiran dan 
kegiatan awam di dunia ini bertujuan mencari dan mewujudkan suatu bentuk tata hidup dunia yang dijiwai oleh semangat kasih, kebaikan, kedamaian, keadilan dan sejahtera sebagaimana dikehendaki Allah sendiri (GS. Art. 7).

\section{TUNTUTAN AKAN KEKUDUSAN HIDUP}

Selain kebaruan dan kesempurnaan hidup, awam juga dipanggil Allah untuk menghayati kekudusan hidup. Panggilan kepada kekudusan hidup ini tidak lain merupakan panggilan untuk menghayati kasih Yesus secara penuh. Kekudusan hidup merupakan kesaksian yang paling anggung dari martabat setiap murid Yesus. Panggilan kepada kekudusan hidup bukan sekedar suatu tuntutan moral tetapi lebih dari itu merupakan tuntutan untuk hidup dalam persekutuan dengan Yesus Kristus sebagai pokok anggur. Ranting-ranting anggur hanya bisa hidup, berkembang dan berbuah bila ranting-ranting itu bertumbuh dan mengambil bagian dalam hidup dan kekudusan Kristus yang memberikan dirinya sendiri untuk kekudusan semua anggota Gereja (Bdk Ef 5: 25-26).

Awam yang terus aktif bekerja di tengah dunia ini dituntut untuk menempuh jalan hidup yang kudus. Jalan hidup yang kudus ialah jalan hidup yang selalu diperbaharui oleh Injil. Rasul Petrus mengingatkan awam sebagai umat beriman dengan berkata: "Tetapi hendaklah kamu menjadi kudus dalam seluruh hidupmu sama seperti Dia yang kudus yang telah memanggil kamu” (1 Ptr 1: 15). Panggilan kepada kekudusan hidup ini berakar dalam pembabtisan dan diperbaharui oleh sakramen-sakramen lainnya terutama sakramen Ekaristi. Setiap umat awam yang telah disatukan dengan Yesus mendapat kekuatan dan kemapuan untuk mewujudkan kekudusan hidup. Rasul St. Paulus tidak pernah bosan menasehati umat beriman untuk hidup "selayaknya sebagai orang kudus" (Ef 5:3).

Panggilan kepada kekudusan hidup menuntut setiap awam sebagai umat beriman untuk hidup sesuai dengan gerakan Roh (Bdk. Rom 6: 22; Gal 5:22), mencontoh hidup Yesus, merenungkan Sabda Allah, berpartisipasi dalam kegiatan liturgi, bertekun dalam doa, memiliki kerinduan dan kehausan akan keadilan, cinta kasih dan semangat pelayanan. Paulus menasehati setiap umat beriman melalui Firman Tuhan: "Dan segala sesuatu yang kamu lakukan dengan perkataan dan perbuatan, lakukan semuanya itu dalam nama Tuhan Yesus, sambil mengucap syukur oleh Dia kepada Allah, Bapa kita” (Kol 3:17). Konsili Vatikan II menegaskan bahwa umat beriman terutama awam yang tidak menata kehidupan keluarga serta kegiatan sekuler selaras dengan rencana dan kehendak Ilahi, sesungguhnya telah berada diluar rencana Ilahi akan kekudusan hidup sebab tuntutan akan kekudusan hidup itu sendiri merupakan dasar kesatuan hidup umat beriman Katolik (Bdk. GS. Art. 12). 
Kaum awam dikuduskan Allah melalui hidup dan kegiatan sehari-hari di tengah dunia dan masyarakat sekularistik. Kaum awam sebagai umat beriman hendaknya memandang hidup dan kegiatannya sehari-hari sebagai kesempatan untuk menyatukan diri sendiri dengan Allah atas cara memenuhi kehendak Allah, melayani sesama manusia dan mengarahkan setiap orang kepada persekutuan hidup dengan Allah dalam Yesus putra Allah (LG. Art.48; GS. Art. 7). Panggilan kepada kekudusan hidup ini merupakan suatu keharusan sekaligus kesaksian konkrit tentang cinta kasih Allah kepada manusia yang bersifat universal dan tidak terbatas. Panggilan kepada kekudusan hidup merupakan suatu tugas perutusan dan tanggung jawab Ilahi yang dipercayakan kepada awam di tengah dunia dan masyarakat. Kekudusan hidup hanya bisa bertumbuh dan berkembang dalam diri seseorang karena persekutuannya dengan Yesus Kristus:

"Sama seperti ranting tidak dapat berbuah dari dirinya sendiri kalau ia tidak tinggal pada pokok anggur, demikian juga kamu tidak berbuah jikalau kamu tidak tinggal di dalam aku. Akulah pokok anggur dan kamu adalah ranting-rantinya. Barangsiapa tinggal di dalam Aku dan Aku di dalam dia, ia berbuah banyak. Sebab diluar Aku kamu tidak dapat berbuat apa-apa” (Joh 15: 4-5).

Kekudusan hidup yang dimiliki awam merupakan bagian dari kekudusan Gereja. Kekudusan hidup ini menuntut awam untuk memberi kontribusi membangun dunia sesuai rencana dan kehendak Allah. Tidak bisa disangkal bahwa saat ini tidak sedikit awam giat bekerja membangun Gereja dan masyarakat karena kesadaran akan panggilan suci ini. Banyak dari kegiatan yang dilakukan tidak terlihat manusia dan dunia, tetapi selalu dilihat oleh Allah Bapa di surga. Kekudusan hidup sebagai awam merupakan sebuah kondisi fundamental yang harus dimiliki setiap awam sebagai anggota Gereja karena kekudusan hidup merupakan dasar kesatuan hidup awam sebagai umat beriman dengan Allah Bapa dan Yesus Kristus Putera Allah(Bdk. LG. Art.48; GS. Art. 7).

\section{KESIMPULAN}

Allah memanggil dan mengutus awam untuk menata dunia melalui berbagai upaya mengatur tata kelola kehidupan keluarga, dunia pendidikan, ekonomi, politik, hukum, sosial, budaya dan lain-lainya seturut kehendak dan rencanaNya dengan tujuan supaya kasih, berkat dan kebaikan Allah itu dapat dialami banyak orang. Di tengah dunia yang sekularistik, awam sebagai Gereja Umat Allah diundang untuk terlibat aktif dalam tata kelola dan pembaharuan dunia seturut kehendak dan rencana Allah. Awam terpanggil untuk mengambil bagian dalam tata kelola dunia yang berdimensi sekularistik atas cara berbeda. Panggilan ini harus direspon dengan penuh iman dan sukacita. 
Wujud konkret fungsi awam menata dunia ini dinyatakan secara konkret melalui berbagai profesi, pekerjaan atau kegiatan awam sehari-hari dalam bidang sosial, budaya, pendidikan, politik, ekonomi, hukum, pemerintahan dll. Semua kegiatan ini perlu dilakukan selaras rencana dan kehendak Allah demi kebaikan dan keselamatan universal. Martabat hidup awam sebagai umat beriman selain terletak pada panggilan Allah dan jawaban atas panggilan Allah untuk menata dunia ini juga terletak pada panggilan untuk menghayati kekudusan, kesempurnaan dan kebaruan hidup. Menghayati kekudusan, kesempurnaan dan kebaruan hidup merupakan suatu tuntutan fundamental bagi awam karena kekudusan, kesempurnaan dan kebaruan hidup ini merupakan dasar kesatuan hidup umat beriman dengan Allah Bapa dan Yesus Kristus Putra Allah.

\section{DAFTAR PUSTAKA}

John Paul II. 1987. Homily at the Solemn Eucharistic Celebration for the Close of the Seventh Ordinary, General Assembly of the Synod of the Bishops Closing Mass

Second Vatican Council, Dogmatic Constitution On the Church, Lumen Gentium (LG). Art. 48

Second Vatican Council, Pastoral Constitution On the Church in the Modern World, Gaudium et Spes. (GS) Art. 7

Second Vatican Counsil. Decree On the Apostolate of the Lay People, Apostolicam Actuositatem (AA). Art.33.

St. Agustne Confessiones 1.1.

St. Gregory the Great. In Evangelization I, xix, 2 PL 76. 1155. 